\title{
The Role of Sustainability for Enhancing Third-Party Logistics Management Performance
}

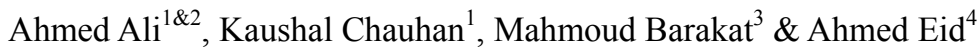 \\ ${ }^{1}$ Universitat Duisburg-Essen Fakultat fur Ingenieurwissenschaften, Duisburg, Nordrhein-Westfalen, DE \\ ${ }^{2}$ Arab Academy for Science Technology and Maritime Transport, Collage of international transport and logistics, \\ logistics and supply chain management department, Alexandria, EG \\ ${ }^{3}$ Arab Academy for Science Technology and Maritime Transport, Collage of international transport and logistics, \\ logistics of international trade department, Alexandria, EG \\ ${ }^{4}$ Arab Academy for Science Technology and Maritime Transport, Collage of international transport and logistics, \\ transport and logistics management department, Alexandria, EG \\ Correspondence: Mahmoud Barakat, Arab Academy for Science Technology and Maritime Transport, Collage of \\ international transport and logistics, logistics of international trade department, Alexandria, EG. E-mail: \\ mahmoud.barakat@aast.edu
}

Received: July 3, 2018 Accepted: December 30, 2018 Online Published: January 24, 2019

doi:10.5539/jms.v9n1p14 URL: https://doi.org/10.5539/jms.v9n1p14

\begin{abstract}
Technological development and globalization made the supply chain more complex in today's business environment. In competitive market conditions, shippers tend to outsource most of their logistical activities to Third-Party Logistics (3PL) service providers. These activities have drawn attention of decision makers regarding sustainability concerns. This study examines sustainability initiatives which have been implemented particularly for the 3PL functions namely; transportation, warehousing and packaging services and their influence on performances. Empirical data have been collected through a worldwide online survey which has been sent to industrial experts working in logistics and supply chain management fields. The results were analyzed through the Structural Equation Modelling (SEM). The analysis indicated that, the 3PL functions significantly affect environmental, economic, social and operational performance, except packaging which had no significant impact on economic, operational and social performance, in addition to transportation which had no significant impact on social performance. Regarding the performance outcome and its impact on logistics efficiency, logistics effectiveness and competitiveness, empirical results indicated that there is no significant impact between the variables except, social performance which had a significant impact on logistics efficiency and competitiveness, operational performance which had a significant impact on logistics efficiency, logistics effectiveness and competitiveness. The proposed model and hypotheses developed give further understanding regarding 3PL industries thereby help decision makers in solving the problems related to 3PL sustainability initiatives.
\end{abstract}

Keywords: 3PL, performances, quantitative research, structural equation modelling (SEM), sustainability

\section{Introduction}

Sustainability is a concept that has been derived to fill the gap between the development and environment. World Commission on Environment and Development (WCED) has defined sustainable development as, "It is not fixed state of harmony, but rather a process of change in which, exploitation of resources, the direction of investments, the orientation of technological development, and the institutional change are made consistent with future as well as present needs." (Brundtland, 1987). Third-party logistics is outsourcing philosophy in logistics and supply chain industry. 3PLs has become worldwide industry that fulfills customer needs through a host of primary and value-added services (Gardner, 2004).

Sustainability causes various impact in all the logistics function of 3PL, it has become a challenging area for 3PL for a highly competitive market. Sustainability is a Holistic approach towards developing solution against challenges and created direct or indirect impact on the logistical performances. The selection of sustainability initiatives is already taken into practice; however there are many aspects that should be considered based on the 
effects on performance in 3PL. Furthermore, the available information does not give a clear image about the impact of sustainability in various management performances. This requires a further study to understand better insights. Therefore, sustainability in 3PL has become more interesting area for further research. Performance related sustainability initiatives should be considered when the major strategic decisions are made in 3PL industries (Evangelista, Huge-Brodin, Issaksson, \& Sweeney, 2013).

The main logistics functions in 3PL are transportation, warehousing, packaging which is mainly focused in this part of the research. This research will further contribute the advance knowledge in literature. It will provide an idea to develop strategic solution within the 3PL industry. The impact of sustainability initiatives will be explained. This research could be helpful to create make decisions for logistics service providers to select sustainability initiatives in future.

\section{Role of 3PL in Logistics and Supply Chains}

3PL has very broad meaning in supply chain and it can be applicable to any contract that includes the storing or shipping of goods. Therefore, 3PL is also known as "contract logistics" (Rouse, 2010), "logistics provider", "third party logistics supplier", "logistics outsourcing" and "logistics alliances" (Selviaridis \& Spring, 2007). Sometimes a single service like transportation, warehousing or many multiple services can be managed by 3PL in the entire supply chain (Rouse, 2010).

Today's global supply chains are facing multiple challenges which includes coordination of supplies in inbound and outbound, storage of goods, inventory management, distribution of finished products through various modes of transport across the countries. Therefore, these types of challenges could become more difficult due to delays, mistakes, miscommunications, human error and accidents (Plunkett, 2009).

Logistics services could be outsourced to satisfy customer demand at low cost and risk. Outsourcing of logistical services have become critical for big industries due to the reason that industries can focus their energies on their core operations which are very important to survive in global competition and give the rest of the responsibility to 3PL providers. The overall scenario about buying logistics service has been increased by following two reasons (Bhatnagar, Sohal, \& Millen, 1999):

- Increase in the number of service provided by 3PL.

- The number of customers of 3PL services has been increased.

3PL act as intermediator between manufacturer or supplier (the party which purchase the service known as shipper) and the end user is customer (consumes the product or service). In this way, 3PL will have to focus on both side and should face challenges which are unique to its operations (Cheong, 2004).

In today's business, it has become difficult to concentrate on methods to increase customer service along with cost controlling. 3PL has become essential to outsource such type of activities and that provides wide range of benefits which are (Evans, 2015):

- Utilization of resources: 3PL can help to save time and cost and make the business efficient in all manners. 3PL reduce the cost of investment in warehouse space, transportation and skilled manpower to execute the logistics process.

- Expertise: 3PLs are very much familiar about the latest developments in logistics, technology and other related fields. They have updated knowledge about the best practices in industry which is useful for the users. Much software used for monitoring entire logistics process, advance reporting, and inventory management improves visibility and makes the process transparent.

- Flexibility and scalability: With the use of 3PL, organizations become more flexible because that made it easier to scale transportation, staff and other resources according to inventory demand. 3PL provider takes all burdens, which make you take seasonal advantages and handle all the transactions smoothly.

- Continuous improvement: Logistics service providers are highly flexible with fluctuations. 3PLs have ability to make the adjustments according to the different circumstances faced in supply chain so that the customer need can be fulfilled as fast as possible in an efficient and in effective manner. In short, 3PL can help to reduce lead time, maximize the profit and improves the quality.

- Use of latest technology: for a complex supply chain process, 3PL offers latest software and technology. Therefore, user should not have to invest in latest developments. 
- Improves growth rate: 3PL allows you to develop your market not only up to state or county, but also to the world. Therefore, business can be expanded with minimal cost which directly affects to growth rate of business.

- Safety: An experienced 3PL provider ensures security by preventing from making huge mistake in decision-making process and assures higher return on investments.

- Customer satisfaction: advanced technology, skilled manpower and multiple asset in 3PL assure that all logistical international level will be satisfied. Therefore, the business can mainly focus on the customer services.

Hence, logistics functions become clearer and faster due to the benefits of using 3PLs.

\section{Sustainability Initiatives in 3PL}

\subsection{Sustainable Transport Initiatives}

3PLs provide transportation services locally and globally to small, medium and large-scale industries and these services have been carried out using a variety of sustainable approaches (Evangelista et al., 2013). See Table 1.

Table 1. Sustainable transportation initiatives

\begin{tabular}{ll}
\hline Sustainability initiative & Examples \\
\hline Alternative fuels & Use of bio fuels, use of renewable energy sources, limitation on fossil fuels or its usage base on \\
& environmental class specific fuel consumption. \\
Vehicle usage & $\begin{array}{l}\text { Replace old fleets, modern and efficient vehicles, regular maintenance. } \\
\text { Selection of transport mode that that give sustainable benefit (air, sea, rail transport or intermodal } \\
\text { transport), load optimization. }\end{array}$ \\
Modify logistical system design & Use direct transport, improvements in distribution network, decrease average length of haul, route \\
& planning-Transport management system (TMS). \\
Choice of partners & $\begin{array}{l}\text { Ask for support of customer to achieve your own environmental targets, selection of environmental } \\
\text { transport provider. }\end{array}$ \\
Emissions and energy data & CO2 reports, consumption from external transportation. \\
Driving behavior & Driver training for consistent performance.
\end{tabular}

Note. Adapted from (Martinsen \& Björklund, 2012).

\subsection{Sustainable Warehousing Initiatives}

Storage is a key function of warehouses. Sustainability in warehousing can be focused on several aspects. From designing of the warehouse to its management and maintenance, sustainability criteria can be considered at various stages. Several sustainability initiatives can be classified based on warehouse design, warehouse management and handling of goods. Initiatives and their examples are listed in Table 2.

Table 2. Sustainable warehousing initiatives

\begin{tabular}{ll}
\hline Sustainability initiative & Examples \\
\hline $\begin{array}{l}\text { Warehouse design } \\
\text { Location }\end{array}$ & $\begin{array}{l}\text { Environment-friendly facility location. } \\
\text { Recycled concrete, asphalt, and other materials. } \\
\text { Lighting }\end{array}$ \\
$\begin{array}{l}\text { Warehouse management } \\
\text { Education }\end{array}$ & Training, awareness programs, seminars. \\
$\begin{array}{l}\text { Working condition } \\
\text { Alternative energy source }\end{array}$ & Ergonomic working environment according to safety and security of employee. \\
$\begin{array}{l}\text { Waste management system } \\
\text { Handling of goods }\end{array}$ & Waste water recycling plants, water storage system, solid waste management system. \\
Material handling & Installation of equipment- Automated guided vehicles (AGV) and automated storage and retrieval \\
& system (ASRS). \\
Warehouse management system & Pick-by-light technology, voice technology, RFID, and other automated solutions. \\
\hline Note. Adapted from (Furtado, 2017; Perotti, Zorzini, Cagno, \& Micheli, 2012).
\end{tabular}

\subsection{Sustainable Packaging}

Packaging plays an important role in storing, handling and transportation of goods, for the individual who is concerned about efficiency and effectiveness of logistical activities. When it comes to sustainable packaging, it 
must be beneficial from the environmental, economic and social point of view. The major sustainable initiatives in packaging are; recycle and reuse of packaging, eco-friendly packaging design, biodegradable packaging materials and customer cooperation (Perotti et al., 2012).

\section{Research Methodology}

A quantitative method is used to investigate relationships between variables through developing a research questions or hypotheses and analyze collected data to test this hypothesis or questions (Creswell, 2014). Since this research is trying to investigate the relationship between two variables, quantitative method will be adapted, through formulated questionnaires in the survey to collect data from the participants. However, before carrying out with the empirical analysis research hypotheses must be developed by examining the theories, the relationships between the sustainability criteria and performance.

\subsection{Hypotheses and Model Development}

Sustainability initiatives in 3PL have an influence on performance outcomes. Environmental performance, economic performance, social performance, operational performances are determined as the four performance measures which have direct relations to the 3PL sustainable initiatives (Gunasekaran, Patel, \& McGaughey, 2004). Indicators of all performance measures are derived. Performance indicators reflect the influence of 3PL function on a specific performance measure. Their relationship is established with each 3PL function. It is also assumed that Logistics efficiency, logistics effectiveness and competitiveness are the other measures on which there is an influence of performances.

Environmental Performance reflects the consequences of 3PL sustainable initiatives on the environment. These initiatives are influencing internally as well as externally to the company. To measure environmental performance following indicators are derived (Ageron, Gunasekaran, \& Spalanzani, 2012; Perotti et al., 2012);

- Reduction of air emission

- Reduction of wastes (solid and liquid waste)

- Decrease of hazardous material consumption

- Decrease of environmental accidents

- Reduction in energy and fuel consumption

- Environment management (ISO 14001 certification and EMAS)

The above indicators describe the changes that occur in the environment due to incorporating sustainability initiatives into 3PL. To check their influence on environment following hypotheses are considered.

H1: Environmental performance improves with the adoption of 3PL sustainable transport initiatives.

H2: Environmental performance improves with the adoption of 3PL sustainable warehousing initiatives.

H3: Environmental performance improves with the adoption of 3PL sustainable packaging initiatives.

Economic performance is defined as the financial achievements that a company gains after adopting sustainable initiatives. To measure economic performance following indicators are derived (Geng, Mansouri, \& Aktas, 2017; Perotti et al., 2012);

- Improvement of market share

- Improvement in revenue

- Increase of investments

- Increase the cost of Eco-friendly materials

- Increase of training cost

- Decrease cost of energy consumption

- Decrease cost of waste treatment

- Decrease fine of environmental accident

Companies recognize economic improvement through company's current situation in the market. Sustainability initiatives could give profits. Therefore, following hypotheses are assumed:

H4: Economic performance improves with the adoption of 3PL sustainable transport initiatives.

H5: Economic performance improves with the adoption of 3PL sustainable warehousing initiatives. 
H6: Economic performance improves with the adoption of 3PL sustainable packaging initiatives.

Social performance: Following social performance indicators are selected to measure impact of sustainability in 3PL (Ashby, Leat, \& Hudson, 2012; Geng et al., 2017; Zailani, Eltayeb, Hsu, \& Tan, 2012);

- Increasing product and company image

- Protecting employee health and safety

- Ensuring customer loyalty and satisfaction

- Short term relationship (in terms of contract)

- Long term relationship (in terms of contract)

- Social responsibility

- Government support

The above factors describe many big organizations are seeking continuously to convince people through adopting sustainable initiatives. Sustainable outcomes could influence on relationships and a company image in their market. To identify the relationship with social performance, following hypotheses are proposed:

H7: Social performance improves with the adoption of 3PL sustainable transport initiatives.

H8: Social performance improves with the adoption of 3PL sustainable warehousing initiatives.

H9: Social performance improves with the adoption of 3PL sustainable packaging initiatives.

Operational performance: “...defined as operational level measures, which include the ability in day-to-day technical representation, adherence to developed schedule, ability to avoid complaints and achievement of defect free deliveries." (Gunasekaran et al., 2004). Following operational performance indicators are selected to measure impact of sustainability in 3PL (Geng et al., 2017; Perotti et al., 2012; Zhu, Sarkis, \& Lai, 2012);

- Improvements of timeliness of goods delivery

- $\quad$ Reduction in inventory levels

- Scrap rate increase

- Improvement in quality of product

- Increase of productivity

- Improvement in capacity utilization

The definition suggests that daily operations are affected through adopting green initiatives. Various operations like storing, maintaining and delivery are affected through sustainability initiatives. Lots of waste can be eliminated through which processes are optimized. Better utilization of resources results in smoother operations in the logistics functions. Therefore, following hypotheses are created to check the influence of 3PL sustainability initiatives on operational performance.

H10: Operational performance improves with the adoption of 3PL sustainable transport initiatives.

H11: Operational performance improves with the adoption of 3PL sustainable warehousing initiatives.

H12: Operational performance improves with the adoption of 3PL sustainable packaging initiatives.

Logistics efficiency: Efficiency describes that how well the resources are utilized economically. The companies are expecting maximum output from the system they are using. Therefore, sustainable initiatives should prove efficient results (Pazirandeh \& Jafari, 2013);

- Administrative cost

- Transport cost

- Inventory cost

- Warehousing cost

- Total logistics cost

- Cost of obsolescence

Companies are expecting high logistics efficiency by improving environmental, economic, social and operational performances. The focus on such performance requires huge amount of investment in terms of times and costs. Sometimes, operation costs are reduced when we are focusing on such performances. On the other side, some 
disadvantages may create the extra costs. Therefore, it is questionable that how this performance affects the logistics efficiency. Hence, the following hypotheses are assumed:

H13: Logistics efficiency improves with environmental performance

H14: Logistics efficiency improves with economic performance

H15: Logistics efficiency improves with social performance

H16: Logistics efficiency improves with operational performance

Logistics effectiveness: It is described as how much extent our objective is accomplished. Following are the indicators selected to measure 3PL effectiveness of various performances (Pazirandeh \& Jafari, 2013);

- $\quad$ Order lead time

- Delivery consistency

- $\quad$ Backorders

- Loss and damage of goods

- Overall reliability

Various performances have their effect on delivery and its timings. They have a direct or indirect effect on 3PL process. Furthermore, performances could have their influence on reliability too. Therefore, following hypotheses are assumed:

H17: Logistics effectiveness improves with environmental performance

H18: Logistics effectiveness improves with economic performance

H19: Logistics effectiveness improves with social performance

H20: Logistics effectiveness improves with operational performance

Competitiveness: Many companies are using performance outcomes as a marketing tool to attract new customers. Improvement is the main tool to achieve competitiveness. Many other indicators can be described as (Ageron et al., 2012; Pazirandeh \& Jafari, 2013);

- Improvement in efficiency

- Quality improvements

- Improvement in productivity/ productivity enhancement

- Cost savings

- $\quad$ Product price

- $\quad$ Flexibility

- Responsiveness

- Develop innovative solutions

Many companies have recognized that their competitiveness is improved by improving performances (Ageron et al., 2012)

To identify which performance influencing competitiveness, following hypotheses are assumed:

H21: Competitiveness improves with environmental performance

H22: Competitiveness improves with economic performance

H23: Competitiveness improves with social performance

H24: Competitiveness improves with operational performance

Based on the above developed hypotheses the proposed model is constructed in Figure 1. 


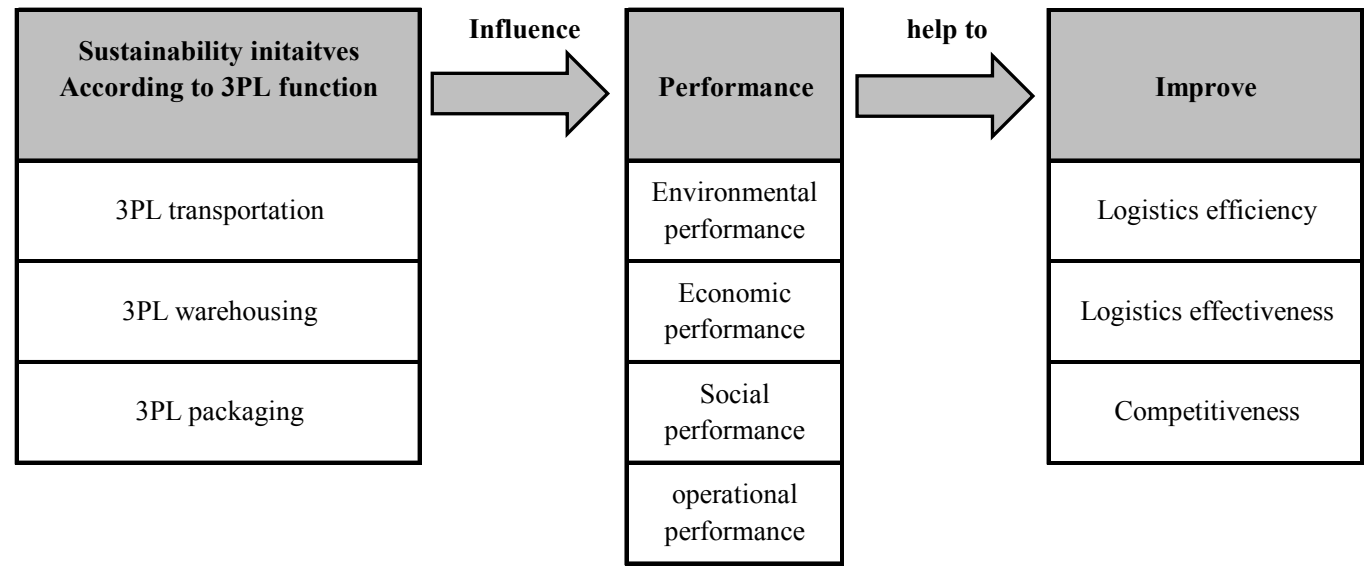

Figure 1. Proposed model—Self-illustrated

\subsection{Formulation of Questionnaires}

Questionnaires are formulated in the survey to collect the data from the participants. Questionnaire is mainly formed in the English language. To contact local respondents, a separate link of questionnaire was generated in the German language.

In all there are 17 number of questions formulated. Questionnaire contains open-ended question in which a participant can easily respond to the maximum number of questions (Creswell, 2014). Those are by using the marking of a radio button or in one-two words or with checklist. The questions 1 to 7 focus on the demographic findings. These questions will collect basic information of the respondent. Questions 8 to 17 represent main part of survey and which are mandatory to be answered. Questions 8 to 10 are formulated to collect the opinions to estimate which sustainability initiative is more effective in a 3PL function. The indicator is represented as a sustainable initiative in a particular logistics function. Questions 11 to 17 collect the opinion about influence of sustainability on various performances. The sub questions are performance indicators. These questions are asked to collect ratings. For this purpose, 5-point Likert scale is used (Brace, 2008). In this method of research, ratings are varied with options "highly effective" to "very less effective" and "very high degree" to "very low degree". However, there was also "no opinion" option available for the respondent. It can be select if they have no specific idea of the question. This form of questions is easy to answer and interpret the data during the analysis.

\subsection{Survey}

Several target groups were searched through keywords like "3PL", "3PL providers", "Contract logistics" and contacts were formed on social professional networks prior to conduct the survey. Participants were also searched according to region or name of some famous logistics service providers or according to the type of industry e.g. Supply chain, Manufacturing, Automotive etc. Most of the requested persons were from logistics, transportation, industrial engineering, material management, packaging, procurement.

Survey questionnaire had been created on Google forms, which offers great flexibility by providing updated data and the use of this service is totally free of cost. The questionnaire was sent to various persons who are associated with 3PL field and have high experience.

\section{Data Analysis and Results}

\subsection{Pilot Study}

In the first phase of the survey, questionnaire was sent to the two hundred industry experts and the first 21 responses were selected to perform the pilot test. Figure 2 and 3 and Table 3 and 4 shows the results of the pilot study regarding composite reliability, average variance extracted (AVE), Fornell-Larcker criterion, and outer loading respectively. 


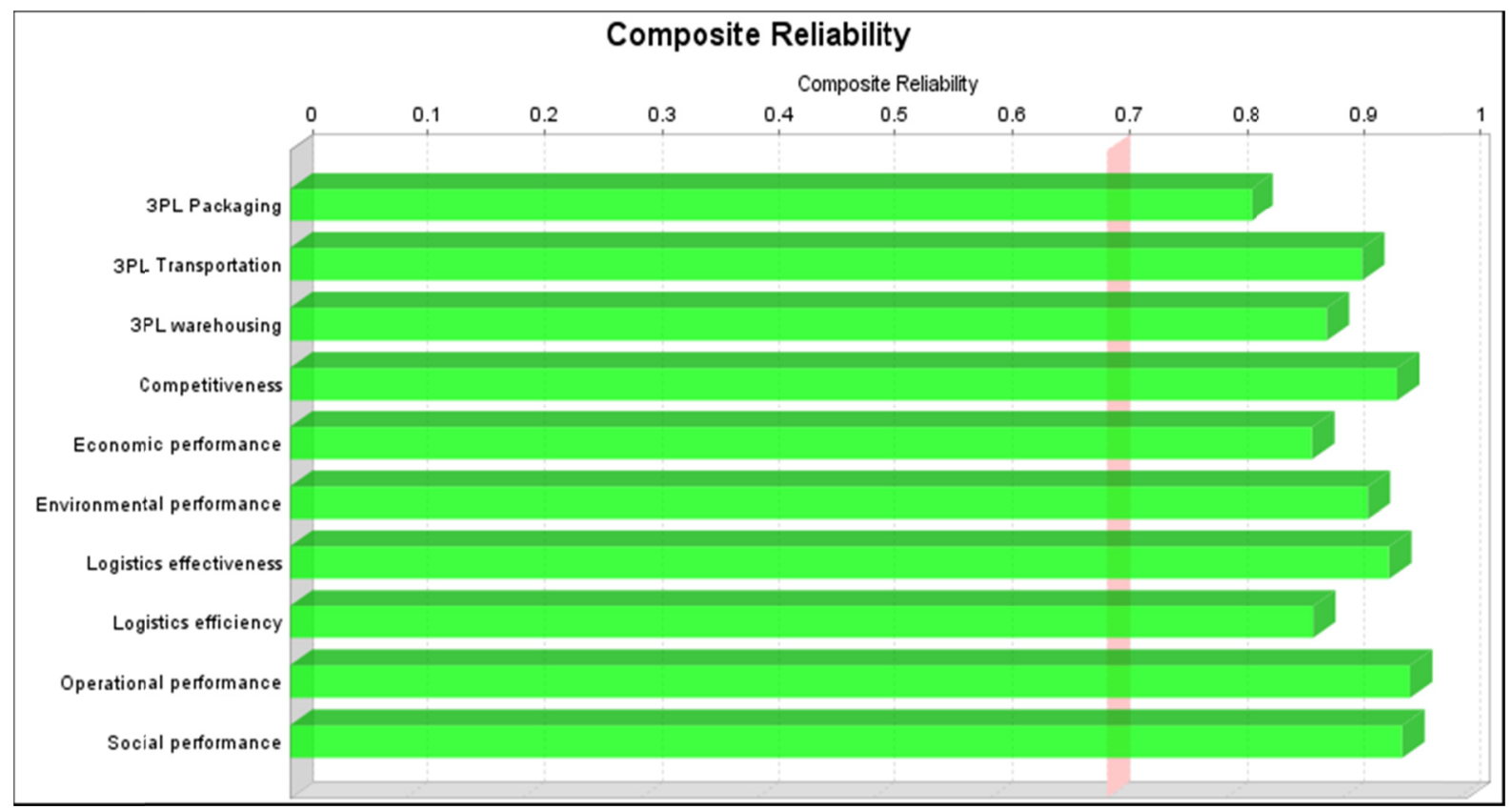

Figure 2. Composite reliability for pilot study

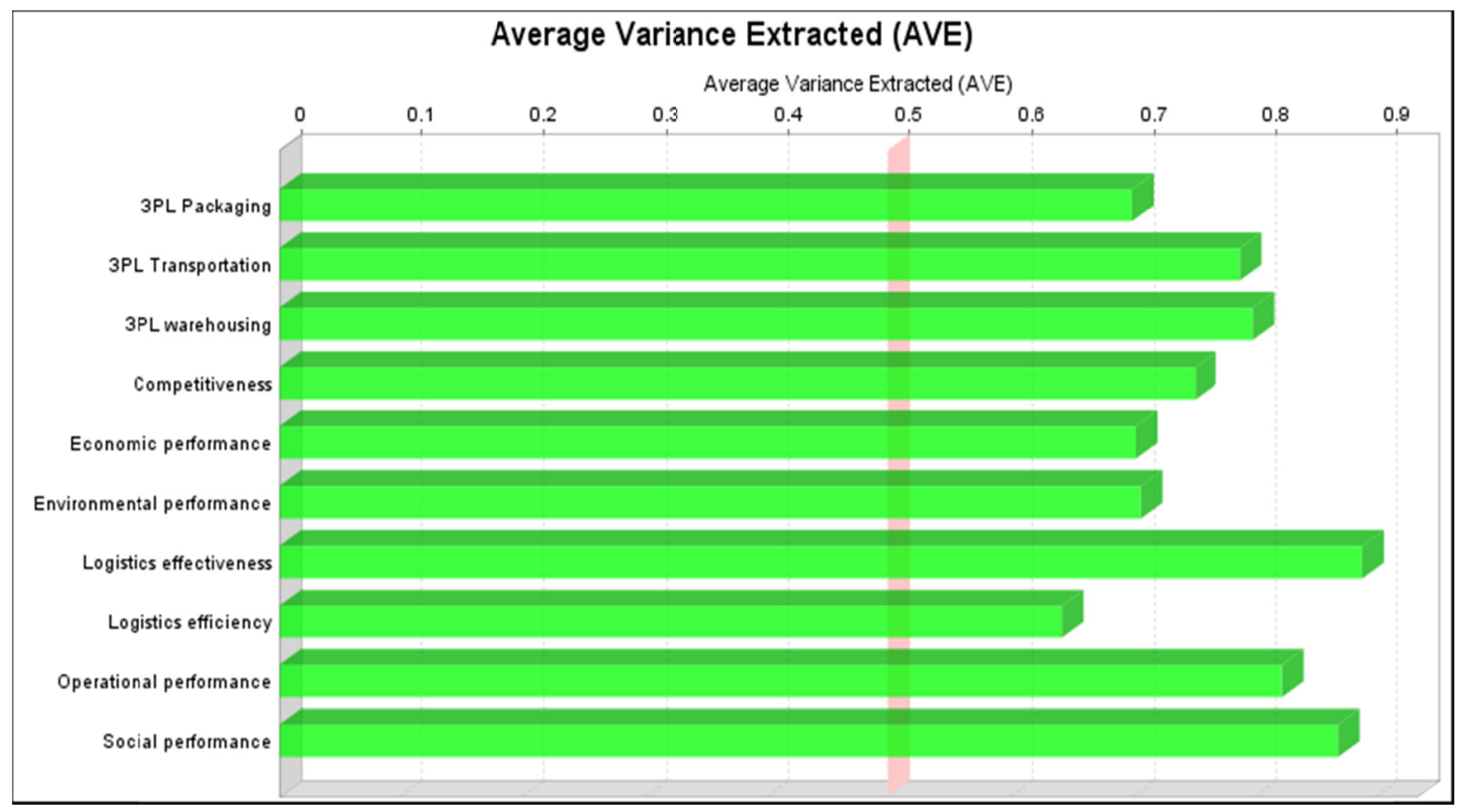

Figure 3. Average variance extracted for pilot study 
Table 3. Fornell-Larcker criterion for pilot study

\begin{tabular}{|c|c|c|c|c|c|c|c|c|c|c|}
\hline & 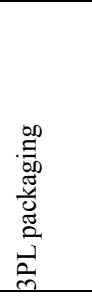 & 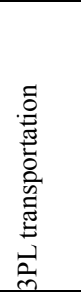 & 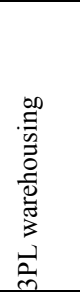 & 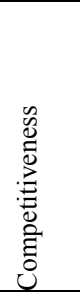 & 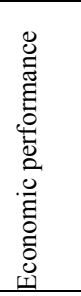 & 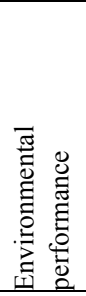 & 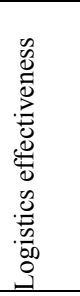 & 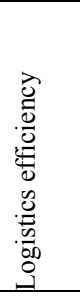 & 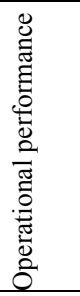 & 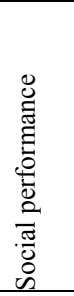 \\
\hline 3PL packaging & 0.836 & & & & & & & & & \\
\hline 3PL transportation & -0.15 & 0.888 & & & & & & & & \\
\hline 3PL warehousing & 0.127 & 0.575 & 0.894 & & & & & & & \\
\hline Competitiveness & -0.114 & 0.73 & 0.654 & 0.867 & & & & & & \\
\hline Economic performance & -0.183 & 0.444 & 0.601 & 0.426 & 0.838 & & & & & \\
\hline Environmental performance & 0.451 & 0.355 & 0.511 & 0.253 & 0.645 & 0.84 & & & & \\
\hline Logistics effectiveness & -0.122 & 0.632 & 0.431 & 0.849 & 0.251 & 0.021 & 0.942 & & & \\
\hline Logistics efficiency & -0.417 & 0.553 & 0.405 & 0.723 & 0.454 & 0.075 & 0.733 & 0.801 & & \\
\hline Operational performance & -0.424 & 0.559 & 0.321 & 0.434 & 0.706 & 0.344 & 0.433 & 0.583 & 0.907 & \\
\hline Social performance & -0.002 & 0.652 & 0.457 & 0.559 & 0.668 & 0.593 & 0.491 & 0.471 & 0.635 & 0.932 \\
\hline
\end{tabular}

Table 4. Outer loading for pilot study

\begin{tabular}{|c|c|c|c|c|c|c|c|c|c|c|}
\hline & 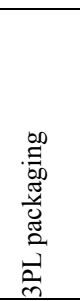 & 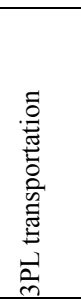 & 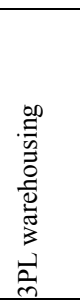 & 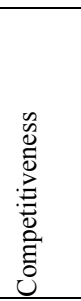 & 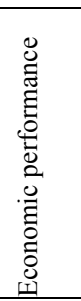 & 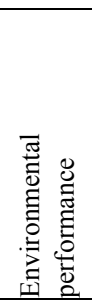 & 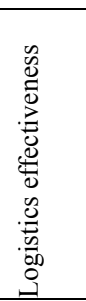 & 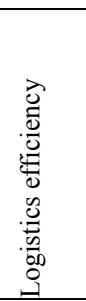 & 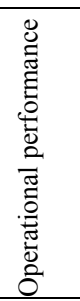 & 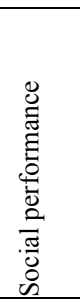 \\
\hline $\mathrm{q} 10.1$ & 0.808 & & & & & & & & & \\
\hline q10.3 & 0.864 & & & & & & & & & \\
\hline q11.1 & & & & & & 0.879 & & & & \\
\hline $\mathrm{q} 11.2$ & & & & & & 0.755 & & & & \\
\hline q11.4 & & & & & & 0.795 & & & & \\
\hline q11.5 & & & & & & 0.956 & & & & \\
\hline q11.6 & & & & & & 0.802 & & & & \\
\hline q12.1 & & & & & 0.758 & & & & & \\
\hline $\mathrm{q} 12.2$ & & & & & 0.823 & & & & & \\
\hline q12.6 & & & & & 0.925 & & & & & \\
\hline q13.3 & & & & & & & & & & 0.922 \\
\hline q13.4 & & & & & & & & & & 0.962 \\
\hline q13.6 & & & & & & & & & & 0.911 \\
\hline q14.1 & & & & & & & & & 0.889 & \\
\hline q14.2 & & & & & & & & & 0.923 & \\
\hline q14.3 & & & & & & & & & 0.83 & \\
\hline q14.5 & & & & & & & & & 0.916 & \\
\hline q14.6 & & & & & & & & & 0.972 & \\
\hline $\mathrm{q} 15.2$ & & & & & & & & 0.72 & & \\
\hline q15.3 & & & & & & & & 0.825 & & \\
\hline q15.4 & & & & & & & & 0.932 & & \\
\hline q15.5 & & & & & & & & 0.708 & & \\
\hline q16.3 & & & & & & & 0.959 & & & \\
\hline q16.4 & & & & & & & 0.926 & & & \\
\hline q17.1 & & & & 0.923 & & & & & & \\
\hline q17.2 & & & & 0.887 & & & & & & \\
\hline q17.3 & & & & 0.904 & & & & & & \\
\hline $\mathrm{q} 17.5$ & & & & 0.786 & & & & & & \\
\hline q17.7 & & & & 0.853 & & & & & & \\
\hline q17.8 & & & & 0.84 & & & & & & \\
\hline q8.6 & & 0.909 & & & & & & & & \\
\hline q8.7 & & 0.89 & & & & & & & & \\
\hline q8.8 & & 0.864 & & & & & & & & \\
\hline q9.4 & & & 0.954 & & & & & & & \\
\hline q9.6 & & & 0.829 & & & & & & & \\
\hline
\end{tabular}


The results of the pilot study insures the validity of the model as composite reliability is above 0.7 , AVE is above 0.5 , Fornell-Larcker criterion is fulfilled as the square root of AVE of a construct is greater than the correlations between the construct and other constructs in model, finally outer loadings criterion is also fulfilled as constructs is always greater than any other loadings of the other constructs (Hair, Hult, Ringle, \& Sarstedt, 2017).

\subsection{Survey Results}

The survey questionnaire was sent to 1080 participants on social professional network. Total 155 persons had participated by filling up this questionnaire. Two of these participants are eliminated because of their positions were unidentified. Total 153 responses were considered for the further tests of the data. Overall response rate was $14.17 \%$. Figure 4 shows classification of respondents according to the type of industry. Table 5 shows the respondents position in their company, company size and characteristics and whether companies has activities on a global level.

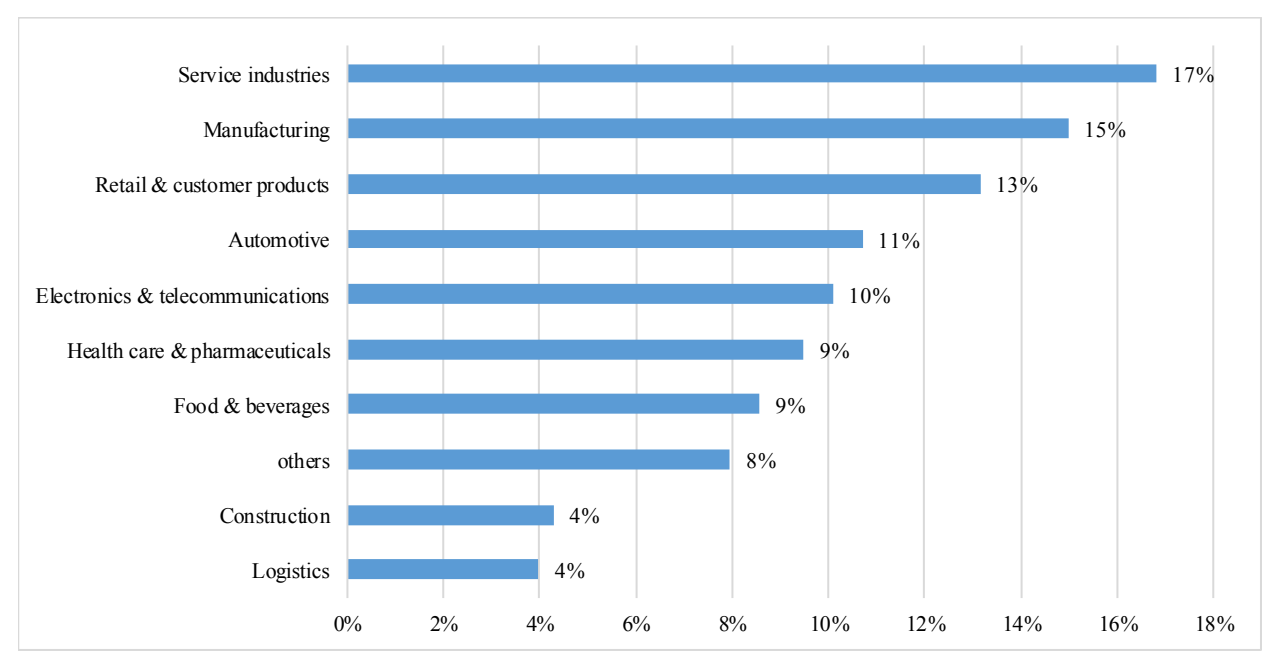

Figure 4. Industry specifics of respondents

Table 5. Demographics findings

\begin{tabular}{lll}
\hline Type of Demographic finding & number of respondents (n=153) & Percentage \\
\hline Company size & & \\
Large (above 5000) & 67 & $44 \%$ \\
Medium (from 1000 to 5000) & 23 & $15 \%$ \\
Small (up to 1000) & 63 & $41 \%$ \\
Company characteristics & & \\
3PL provider & 79 & $52 \%$ \\
3PL User (Customer or Shipper) & 63 & $41 \%$ \\
Non-user/ past user or past customer or past shipper & 11 & $7 \%$ \\
Geographical coverage & & \\
Global / International & 128 & $84 \%$ \\
Local & 25 & $16 \%$ \\
Respondent profile & & \\
Manager & 60 & $39 \%$ \\
Director & 24 & $16 \%$ \\
Others & 12 & $8 \%$ \\
Head & 11 & $7 \%$ \\
Vice president & 9 & $6 \%$ \\
Leader & 9 & $6 \%$ \\
CEO & 8 & $5 \%$ \\
Sr. Executive & 4 & $3 \%$ \\
Supervisor & 4 & $3 \%$ \\
Deputy manager & 3 & $2 \%$ \\
Specialist & 3 & $2 \%$ \\
Jr. Manager & 2 & $1 \%$ \\
Assistant director & 1 & $1 \%$ \\
Engineer & 1 & $1 \%$ \\
Controller & 1 & $1 \%$ \\
Consultant & 1 & $1 \%$ \\
\hline & & \\
\hline
\end{tabular}




\subsection{Model Evaluation}

Research model can be analyzed in two phases. First, there are several tests followed in the measurement model validation, which includes internal consistency reliability, indicator reliability, convergent validity and discriminate validity tests are conducted to validate the measurement model. In the second phase, the model is validated by determining path coefficients and coefficient of determinations through which hypotheses is tested to determine whether it will be accepted or rejected. Table 6 shows the tests performed for the measurement and structural model and their guidelines.

Table 6. Validation criteria

\begin{tabular}{|c|c|}
\hline Type & Guidelines \\
\hline \multicolumn{2}{|c|}{ Measurement model validation } \\
\hline \multicolumn{2}{|c|}{ Internal consistency reliability } \\
\hline Composite reliability (CR) & Above 0.7 (For exploratory research) \\
\hline \multicolumn{2}{|l|}{ Convergent validity } \\
\hline Indicator reliability & All indicator's value Above 0.7 \\
\hline Average variance extracted (AVE) & Above 0.5 \\
\hline \multicolumn{2}{|l|}{ Discriminant validity } \\
\hline Cross loading & $\begin{array}{l}\text { Indicator value should be highest for the respective construct than other } \\
\text { indicators of other constructs }\end{array}$ \\
\hline Fornell-Larcker criterion & $\begin{array}{l}\text { The square root of AVE of a construct must be greater that correlations } \\
\text { between the construct and other constructs in model }\end{array}$ \\
\hline \multicolumn{2}{|c|}{ Structural model validation } \\
\hline Path coefficient $(ß)$ & Ranges between +1 and -1 \\
\hline t value & 1.96 \\
\hline Coefficient of determination $\left(\mathrm{R}^{2}\right)$ & Ranges between 0 and 1 \\
\hline Note: Significance level 0.05 & \\
\hline
\end{tabular}

Note. Adapted from (Hair et al., 2017).

Structural equation modeling (SEM) is used in SmartPLS software which allows a researcher to analyze variables which are not directly measurable (Hair et al., 2017).

First step of research analysis is to prepare a path model; a path model is a graphical representation of variables based on theory and logic that visually describes the hypotheses to be examined. It has two elements namely a structural model and a measurement model (Hair et al., 2017).

Figure 5 shows the structural model which shows the sequence of research model from left to right and three types of variables. It has independent variables on the left side which are predictor. These are the constructs which are termed as exogeneous latent variables. These variables have arrows pointing out of them. Dependent variables are the outcomes constructed at the right side and they have arrows pointing into them. Mediator variables always appear in the middle as they have dual relationship. They have arrows coming in from the one side and coming out from the other side. In this research model, all the 3PL functions are independent variables as they are predicting influence on performances and the mediator variables are performances.

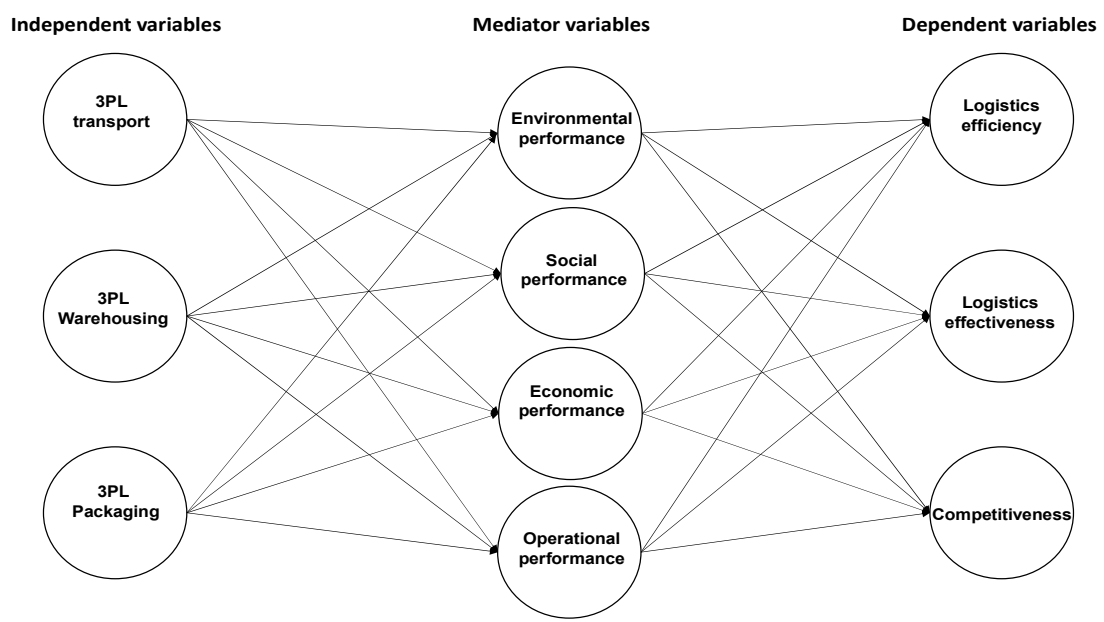

Figure 5. Structural model 
Reflective measurement model

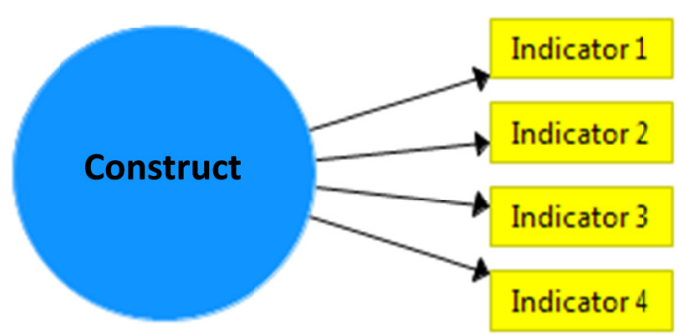

\section{Formative measurement model}

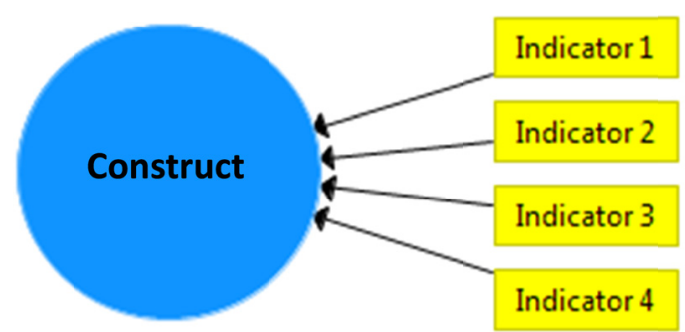

Figure 6. Types of measurement model

\subsubsection{Internal Consistency Reliability}

Reliability describes how the results are close to each other. There are two criterions to measure internal consistency. Typically, Cronbach's alpha is a traditional criterion to measure internal consistency reliability. The test gives an estimation of reliability by checking inter-correlations of the observed indicator variables. Reliability tests were conducted in SPSS statistical software. Ideally, the value of Cronbach's alpha should be above 0.7 (Hair et al., 2017). Error! Reference source not found.7 describes the test results. Cronbach's alpha is dependent on the number of indicators in each construct. Therefore, it can be improved by removal of certain indicators to reduce measurement error in the analysis Once a value reaches to a certain threshold point, it is impossible to improve the value. However, only in some constructs, it was required to improve the values. The other constructs have already a threshold values which can't be improved further. For example, Cronbach's alpha is improved to 0.751 by eliminating usage of alternative fuel in 3PL transport.

Table 7. Cronbach's alpha test

\begin{tabular}{llll}
\hline Construct & Indicators deleted & Cronbach's alpha & Improved Cronbach's alpha \\
\hline 3PL transportation & Usage of alternative fuel & 0.745 & 0.751 \\
3PL warehousing & - & 0.833 & 0.833 \\
3PL packaging & - & 0.628 & 0.628 \\
Environmental performance & - & 0.810 & 0.810 \\
Economic performance & - & 0.855 & 0.855 \\
Social performance & Short term relationship, Government support & 0.816 & 0.838 \\
Operational performance & - & 0.915 & 0.915 \\
Logistics efficiency & Administrative costs, Inventory costs, Costs of & 0.841 & 0.887 \\
& obsolescence & 0.905 & \\
Logistics effectiveness & - & 0.894 & 0.905 \\
Competitiveness & - & & 0.894 \\
\hline
\end{tabular}

Cronbach's alpha does not give an appropriate detail about individual reliability of indicator. SmartPLS overcomes this limitation by prioritizing the indicators according to individual reliability. Therefore, it is more suitable to apply composite reliability to measure internal consistency reliability. This measure is dependent on the outer loadings of indicator variables. The value of composite reliability varies between 0 and 1 . Higher value indicates higher composite reliability. Normally, values between 0.60 and 0.70 are accepted in exploratory research. However, values above 0.70 are considered as satisfactory (see Table 6).

\subsubsection{Convergent Validity}

Convergent validity is the extent to which an indicator correlates positively with the other indicator of the same construct. For convergent validity, outer loadings of indicators and average variance extracted (AVE) are considered (Hair et al., 2017). From the use of Smart-PLS algorithm function, the values of all criterions were obtained. If the values were below the recommended guidelines shown in table 4, then the indicator with lowest loading value was eliminated at each algorithm run. In this way, CR, indicator reliability and AVE values were 
improved and measurement model has been validated. The final values and average variance of all constructs are displayed in Table 8 and 9 respectively.

Table 8. Model validation

\begin{tabular}{|c|c|c|c|}
\hline Cross loadings & Construct and indicators & Outer loading & t values \\
\hline & 3PL transportation $(\mathrm{CR}=0.852)(\mathrm{AVE}=0.657)$ & & \\
\hline q8.6 & Emission and energy data & 0.818 & 20.980 \\
\hline q8.7 & Choice of partners & 0.815 & 17.914 \\
\hline \multirow[t]{2}{*}{$\mathrm{q} 8.8$} & Driving behavior & 0.799 & 19.341 \\
\hline & 3PL warehousing $(\mathrm{CR}=0.843)(\mathrm{AVE}=0.642)$ & & \\
\hline q9.1 & Education & 0.797 & 18.975 \\
\hline $\mathrm{q} 9.2$ & Environment friendly facility location & 0.808 & 16.875 \\
\hline \multirow[t]{2}{*}{ q9.3 } & Consideration of construction materials & 0.798 & 16.992 \\
\hline & 3PL packaging $(\mathrm{CR}=0.840)(\mathrm{AVE}=0.725)$ & & \\
\hline q10.1 & Recycle or reuse of packaging & 0.799 & 8.082 \\
\hline \multirow[t]{2}{*}{ q10.2 } & Eco-friendly packaging design & 0.900 & 14.987 \\
\hline & Environmental performance $(\mathrm{CR}=0.853)(\mathrm{AVE}=0.592)$ & & \\
\hline q11.1 & Reduction of air emission & 0.816 & 23.090 \\
\hline $\mathrm{q} 11.2$ & Reduction of wastes & 0.751 & 15.700 \\
\hline $\mathrm{q} 11.4$ & Decrease of environmental accidents & 0.773 & 18.942 \\
\hline \multirow[t]{2}{*}{ q11.5 } & Reduction in energy consumption / fuel consumption & 0.734 & 12.797 \\
\hline & Economic performance $(\mathrm{CR}=0.882)(\mathrm{AVE}=0.599)$ & & \\
\hline $\mathrm{q} 12.1$ & Improvement of market share & 0.749 & 13.974 \\
\hline $\mathrm{q} 12.2$ & Improvement in revenue & 0.742 & 13.733 \\
\hline q12.6 & Decrease cost of energy consumption & 0.815 & 26.582 \\
\hline $\mathrm{q} 12.7$ & Decrease cost of waste treatment & 0.785 & 14.091 \\
\hline \multirow[t]{2}{*}{ q12.8 } & Decrease fine of environmental accident & 0.775 & 15.044 \\
\hline & Social performance $(\mathrm{CR}=0.891)(\mathrm{AVE}=0.674)$ & & \\
\hline $\mathrm{q} 13.2$ & Protecting employee health and safety & 0.751 & 14.625 \\
\hline q13.3 & Ensuring customer loyalty and satisfaction & 0.755 & 13.904 \\
\hline q13.4 & Length of relationship & 0.894 & 47.803 \\
\hline \multirow[t]{2}{*}{ q13.6 } & Long term relationship & 0.873 & 36.217 \\
\hline & Operational performance $(\mathrm{CR}=0.934)(\mathrm{AVE}=0.703)$ & & \\
\hline $\mathrm{q} 14.1$ & Improvements in timeliness of goods delivery & 0.858 & 33.611 \\
\hline $\mathrm{q} 14.2$ & Reduction in inventory levels & 0.859 & 37.851 \\
\hline $\mathrm{q} 14.3$ & Scrap rate increase & 0.729 & 16.166 \\
\hline q14.4 & Improvement in quality of product & 0.764 & 19.325 \\
\hline $\mathrm{q} 14.5$ & Increase of productivity & 0.909 & 63.343 \\
\hline \multirow[t]{2}{*}{ q14.6 } & Improvement in capacity utilization & 0.898 & 48.054 \\
\hline & Logistics efficiency $(\mathrm{CR}=0.931)(\mathrm{AVE}=0.817)$ & & \\
\hline $\mathrm{q} 15.2$ & Transport costs & 0.875 & 27.628 \\
\hline q15.4 & Warehousing costs & 0.903 & 36.741 \\
\hline \multirow[t]{2}{*}{ q15.5 } & Total logistics costs & 0.933 & 54.981 \\
\hline & Logistics effectiveness $(\mathrm{CR}=0.930)(\mathrm{AVE}=0.726)$ & & \\
\hline q16.1 & Order lead time & 0.881 & 31.777 \\
\hline $\mathrm{q} 16.2$ & Delivery consistency & 0.890 & 38.143 \\
\hline q16.3 & Back orders & 0.849 & 28.825 \\
\hline q16.4 & Loss and damage of goods & 0.792 & 20.017 \\
\hline \multirow[t]{2}{*}{ q16.5 } & Overall reliability & 0.845 & 24.605 \\
\hline & Competitiveness $(\mathrm{CR}=0.912)(\mathrm{AVE}=0.599)$ & & \\
\hline q17.1 & Improvement in efficiency & 0.819 & 21.407 \\
\hline $\mathrm{q} 17.2$ & Quality improvements & 0.791 & 16.127 \\
\hline $\mathrm{q} 17.3$ & Improvement in productivity & 0.862 & 33.682 \\
\hline q17.5 & Product price & 0.716 & 13.859 \\
\hline q17.6 & Flexibility & 0.719 & 12.035 \\
\hline $\mathrm{q} 17.7$ & Responsiveness & 0.774 & 15.444 \\
\hline $\mathrm{q} 17.8$ & Develop innovative solutions & 0.727 & 13.921 \\
\hline
\end{tabular}


Table 9. Average variance of all constructs

\begin{tabular}{ll}
\hline Construct & Average variance Extracted (AVE) \\
\hline 3PL transportation & 0.657 \\
3PL warehousing & 0.642 \\
3PL packaging & 0.725 \\
Environmental performance & 0.592 \\
Economic performance & 0.599 \\
Social performance & 0.674 \\
Operational performance & 0.703 \\
Logistics efficiency & 0.817 \\
Logistics effectiveness & 0.726 \\
Competitiveness & 0.599 \\
\hline
\end{tabular}

\subsubsection{Discriminant Validity}

It tests empirically whether constructs are significantly different form each other, in other words, each construct must be unique (Hair et al., 2017). Results of Fornell-Larcker criterion in table 10 indicate that values are higher than the rest of the correlation with the specific constructs. Hence, Fornell-Larcker criterion is fulfilled and all the constructs have discriminant validity.

Table 10. Fornell-Larcker criterion

\begin{tabular}{|c|c|c|c|c|c|c|c|c|c|c|}
\hline & $(1)$ & (2) & (3) & (4) & $(5)$ & $(6)$ & (7) & $(8)$ & (9) & $(10)$ \\
\hline 3PL Transportation (1) & 0.811 & & & & & & & & & \\
\hline 3PL Warehousing (2) & 0.492 & 0.801 & & & & & & & & \\
\hline 3PL packaging (3) & 0.135 & 0.393 & 0.851 & & & & & & & \\
\hline Competitiveness (4) & 0.209 & 0.291 & 0.149 & 0.774 & & & & & & \\
\hline Economic performance (5) & 0.357 & 0.388 & 0.211 & 0.446 & 0.774 & & & & & \\
\hline Environmental performance (6) & 0.381 & 0.461 & 0.325 & 0.350 & 0.588 & 0.769 & & & & \\
\hline Logistics effectiveness (7) & 0.152 & 0.196 & 0.075 & 0.671 & 0.423 & 0.356 & 0.852 & & & \\
\hline Logistics efficiency (8) & 0.018 & 0.316 & 0.019 & 0.574 & 0.395 & 0.275 & 0.528 & 0.904 & & \\
\hline Operational performance (9) & 0.352 & 0.301 & 0.012 & 0.469 & 0.667 & 0.448 & 0.546 & 0.446 & 0.839 & \\
\hline Social performance (10) & 0.337 & 0.466 & 0.201 & 0.465 & 0.538 & 0.524 & 0.419 & 0.395 & 0.502 & 0.821 \\
\hline
\end{tabular}

Note. Square root of AVE on the diagonal.

Cross loading analysis is another criterion to check discriminant validity. Error! Reference source not found. 8 shows the cross loadings where indicators are specified in rows and constructs are displayed in column. Indicator's outer loadings with the associated constructs must be always greater than any other loadings of the other constructs. For example, 3PL transportation has q8.6, q8.7, q8.8 associated indicators. These indicators have greater loading value then other constructs.

\subsubsection{Hypotheses Testing}

After validation of the measurement model, the hypotheses are tested through the construct model. Structural model represents hypothesized relationships between the constructs. The value of $t$ and path coefficient (B) has been obtained. The minimum t value is 1.96 at significance level of $5 \%$ and the path coefficient values vary between -1 and +1 . However, $t$ values below 1.96 and path coefficient values below 0 are not statistically significant and represent weak relations between the two constructs (Hair et al., 2017). Therefore, if any of the obtained values falls below the criteria, then hypotheses must be rejected. Hypotheses are supported where both $\mathrm{t}$-value is above 1.96 as well as path coefficient is positive and above 0 .

Error! Reference source not found.11 shows the hypothesized relationship between the constructs in research model. Hypotheses results of $\mathrm{H} 1, \mathrm{H} 4$, and $\mathrm{H} 10$ explain that the sustainable transport initiatives have a positive impact on environmental, economic and operational performance.

Hypothesis $\mathrm{H} 7$ has $\beta=0.144$ which fulfills criteria but $\mathrm{t}=1.521$ which was lower than 1.96 therefore hypothesis has been rejected. That explains that social performance does not improve with adopting 3PL transport initiatives.

Hypothesis $\mathrm{H} 7$ has $\beta=0.144$ which fulfills criteria but $\mathrm{t}=1.521$ which was lower than 1.96 therefore hypothesis has been rejected. That explains that social performance does not improve with adopting 3PL transport initiatives 
3PL sustainable warehousing has a great positive impact on 3PL performances as all the hypotheses $\mathrm{H} 2, \mathrm{H} 5, \mathrm{H} 8$, and $\mathrm{H} 11$ related to $3 \mathrm{PL}$ warehousing and performances have been supported.

On the other hand, only environmental performance has been improved by adopting sustainable packaging initiatives which has been proved by hypothesis $\mathrm{H} 3$.

Furthermore, from the results of hypotheses H13, H14, H15, H16, it can be concluded that the logistics efficiency is only improved in hypothesis H16 from social and operational performance. The values of hypothesis $\mathrm{H} 20$ explain that the logistics effectiveness has been improved by operational performance. Environmental performance, economic performance and social performance do not have influence on the logistics effectiveness which is proved by rejection of hypotheses H17, H18, H19 respectively.

The values of hypotheses $\mathrm{H} 21$ and $\mathrm{H} 22$ are not statistically significant. Therefore, it can be proved that the environmental. Performance and the economic performance do not help to improve the competitiveness. Meanwhile, competitiveness can be improved by social and operational performance which is identified by hypotheses $\mathrm{H} 23$ and $\mathrm{H} 24$ respectively.

Table 11. Hypotheses results

\begin{tabular}{|c|c|c|c|c|}
\hline Hypothesis & & $\beta$ values & $\mathrm{t}$ values & Testing result \\
\hline H1 & 3PL Transportation $\rightarrow$ Environmental performance & 0.218 & 2.831 & Support \\
\hline $\mathrm{H} 2$ & 3PL Warehousing $\rightarrow$ Environmental performance & 0.281 & 2.942 & Support \\
\hline $\mathrm{H} 3$ & 3PL packaging $\rightarrow$ Environmental performance & 0.185 & 2.618 & Support \\
\hline $\mathrm{H} 4$ & 3PL Transportation $\rightarrow$ Economic performance & 0.225 & 2.736 & Support \\
\hline H5 & 3PL Warehousing $\rightarrow$ Economic performance & 0.245 & 2.499 & Support \\
\hline H6 & 3PL packaging $\rightarrow$ Economic performance & 0.084 & 0.821 & Reject \\
\hline $\mathrm{H} 7$ & 3PL Transportation $\rightarrow$ Social performance & 0.144 & 1.521 & Reject \\
\hline $\mathrm{H} 8$ & 3PL Warehousing $\rightarrow$ Social performance & 0.382 & 4.237 & Support \\
\hline H9 & 3PL packaging $\rightarrow$ Social performance & 0.031 & 0.366 & Reject \\
\hline $\mathrm{H} 10$ & 3PL Transportation $\rightarrow$ Operational performance & 0.260 & 3.228 & Support \\
\hline H11 & 3PL Warehousing $\rightarrow$ Operational performance & 0.215 & 2.331 & Support \\
\hline H12 & 3PL packaging $\rightarrow$ Operational performance & -0.108 & 1.246 & Reject \\
\hline H13 & Environmental performance $\rightarrow$ Logistics efficiency & -0.024 & 0.182 & Reject \\
\hline H14 & Economic performance $\rightarrow$ Logistics efficiency & 0.113 & 0.787 & Reject \\
\hline $\mathrm{H} 15$ & Social performance $\rightarrow$ Logistics efficiency & 0.208 & 2.008 & Support \\
\hline H16 & Operational performance $\rightarrow$ Logistics efficiency & 0.277 & 2.412 & Support \\
\hline H17 & Environmental performance $\rightarrow$ Logistics effectiveness & 0.076 & 0.637 & Reject \\
\hline H18 & Economic performance $\rightarrow$ Logistics effectiveness & 0.008 & 0.069 & Reject \\
\hline H19 & Social performance $\rightarrow$ Logistics effectiveness & 0.162 & 1.573 & Reject \\
\hline $\mathrm{H} 20$ & Operational performance $\rightarrow$ Logistics effectiveness & 0.425 & 4.425 & Support \\
\hline $\mathrm{H} 21$ & Environmental performance $\rightarrow$ Competitiveness & 0.031 & 0.307 & Reject \\
\hline $\mathrm{H} 22$ & Economic performance $\rightarrow$ Competitiveness & 0.130 & 1.082 & Reject \\
\hline $\mathrm{H} 23$ & Social performance $\rightarrow$ Competitiveness & 0.259 & 2.886 & Support \\
\hline $\mathrm{H} 24$ & Operational performance $\rightarrow$ Competitiveness & 0.238 & 2.051 & Support \\
\hline
\end{tabular}

\subsubsection{Empirically Validated Model}

Basically, the coefficient of determination $\left(\mathrm{R}^{2}\right)$ is used as a measure to validate the model. $\mathrm{R}^{2}$ value indicates the combined effects of independent variables on the dependent variables. In a simplified manner, it describes the amount of variance in dependent variable due to the independent variables connected with it. $\mathrm{R}^{2}$ value varies from 0 to 1 . Higher value indicates the higher level in the prediction accuracy (Hair et al., 2017). The empirically validated model is shown in Figure 7. 


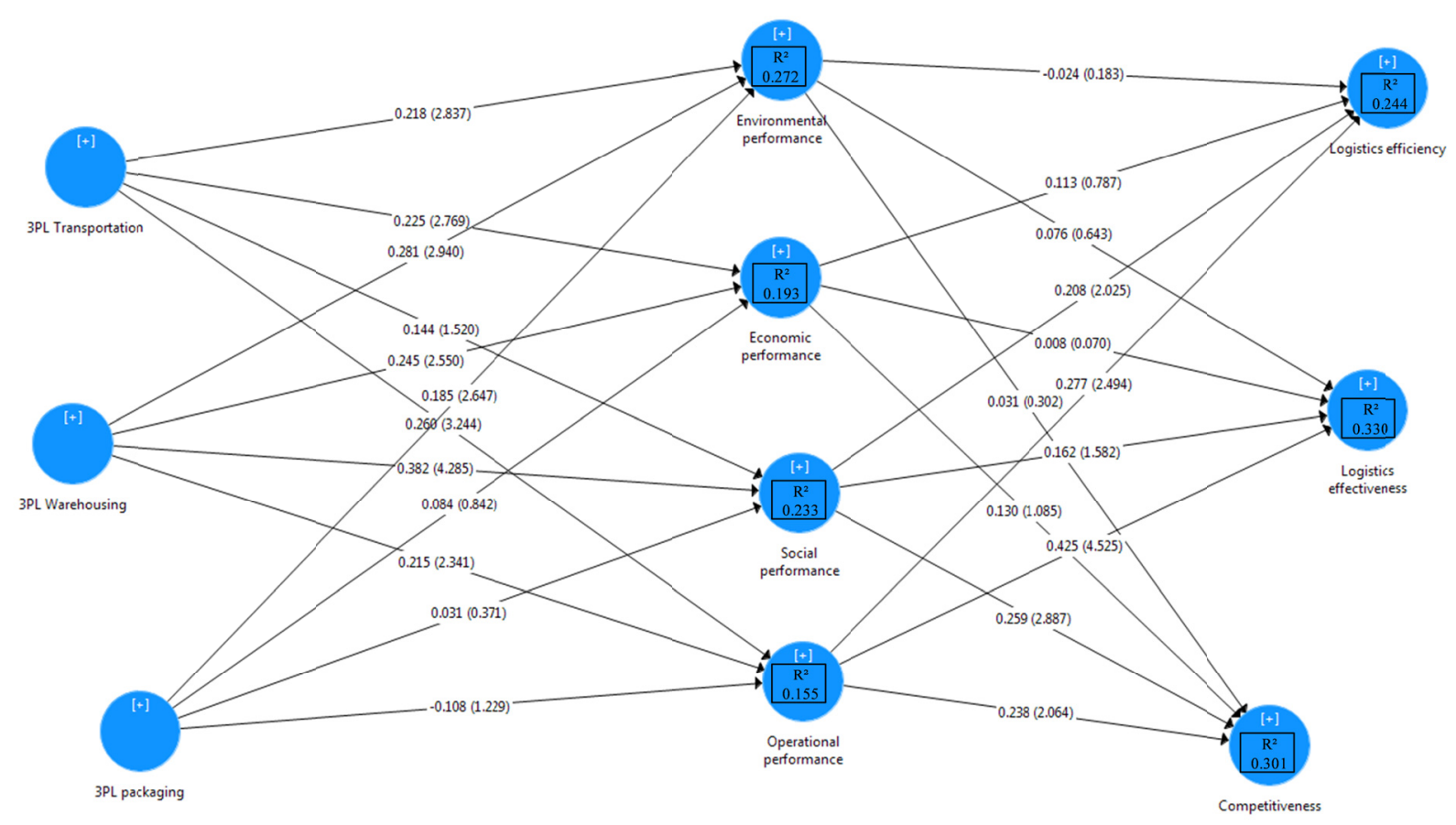

Figure 7. Empirically validated model—Self-illustrated

\section{Conclusion}

This study has analyzed the sustainability practices in 3PL and its connection with the performances. The aim of this work was to understand the effect on organizations performance measures due to implementation of the sustainability practices. This research extrudes the complex challenges of sustainability initiatives faced by 3PLs in the regular practices. The research findings indicate that the advanced research of sustainability and their outcomes have gained importance which has opened a wide field of research. It has found that the sustainable concerns are key elements of the environmental, economic, social and operational performances. It has also found that the 3PL which uses these sustainability initiatives, have significant influenced the logistics efficiency, effectiveness and competitiveness.

Empirical findings from the survey data analysis indicate that the 3PL sustainability initiatives of logistics functions have an influence over the environmental performance. This means adoption of sustainable initiatives in transportation, warehousing and packaging leads in the improvement of the environmental performance. Positive hypothesized relationships between warehousing and all performances indicate that the adoption of sustainability in warehousing gives performance improvements overall.

From the other results of hypotheses testing, it has been concluded that there is a strong association of operational performance with logistics efficiency, logistics effectiveness and competitiveness. Additionally, the hypotheses results describe that social performance which also improves Logistics efficiency and company's competitiveness.

Theoretically, this research provides the understanding of some 3PL sustainability practices and their effect on the selected performance measures. This study adds more knowledge of the performance measures for sustainability. Practically, this research study is useful for decision makers to select which means of sustainability are most beneficial in a particular logistics function.

\subsection{Recommendation for Future Research}

Sustainability initiatives in logistical activities are very broad and complex field of research. There are wide range services provided by 3PLs, but this research study was specific to transport, warehousing and packaging. They have also variety of initiatives implemented by different 3PL providers in variety of logistical functions and few of them are considered for the research based on literatures. As a future scope, it is possible to examine the influence of some other sustainability practice with selecting some other performance indicators. The survey 
was conducted with variety of industries around the world. Therefore, it can be further extended by analyzing sustainability impacts into a specific industrial sector and for some specific regions through which some other specific potentials can be identified.

This research is based on general perceptions of the industry experts from the survey questionnaire. The performance variables are only beneficial if the organizations have implemented sustainability initiatives which are investigated in this research, but the performance impacts founded in this study will give an overview of the influence of specific initiatives. Therefore, the detailed research is needed for a company before investing in investment in such sustainability programs. The study was exploratory in nature and the analysis was conducted with sample size of 153. Large number of answers will provide more accurate results

\section{References}

Ageron, B., Gunasekaran, A., \& Spalanzani, A. (2012). Sustainable supply management: An empirical study. International Journal Production Economics, 168-182. https://doi.org/10.1016/j.ijpe.2011.04.007

Ashby, A., Leat, M., \& Hudson, S. M. (2012). Making connections: a review of supply chain management and sustainability literature. International Journal of Supply Chain Management, 17(5), 497-516. https://doi.org/10.1108/13598541211258573

Bhatnagar, R., Sohal, A. S., \& Millen, R. (1999). Third party logistics services: a Singapore perspective. International Journal of Physical Distribution \& Logistics Management, 29(9), 569-587.

Brace, I. (2008). Questionnaire design. London: Kogan Page.

Brundtland, G. H. (1987). Report of the World Commission on Environment and Development: Our Common Future. Oslo: World Commission.

Cheong, M. L. (2004). Logistics outsourcing and 3PL challenges.

Creswell, J. W. (2014). Research design: qualitative, quantitative, and mixed method approaches. California: SAGE Publications.

Evangelista, P., Huge-Brodin, M., Isaksson, K., \& Sweeney, E. (2013). Implications from the Environmental Sustainability Attitude of 3PLs. Purchasing Green Transport and Logistics Services, 1, 86-102.

Evans. (2015). Outsourcing to a 3PL: Top 10 Reasons. Retrieved January 6, 2018, from https://www.evansdist.com/outsourcing-3pl-top-10-reasons/

Furtado, P. (Producer). (2017). abelwomack. Retrieved from http://www.abelwomack.com/sustainable-logistics-the-warehousing-approach/

Gardner, D. L. (2004). Supply Chain Vector: Methods for Linking the Execution of Global Business Models with Financial Performance. Florida: J. Ross Publishing.

Geng, R., Mansouri, A. S., \& Aktas, E. (2017). The relationship between green supply chain management and performance: A meta-analysis of empirical evidences in Asian emerging economies. International Journal of Production Economics, 245-258. https://doi.org/10.1016/j.ijpe.2016.10.008

Gunasekaran, A., Patel, C., \& McGaughey, E. R. (2004). A framework for supply chain performance measurement. International Journal of Production Economics, 87, 333-347. https://doi.org/10.1016/j.ijpe.2003.08.003

Hair, J. F., Hult, T. M., Ringle, C. M., \& Sarstedt, M. (2017). A primer on Partial Least Squares Structural Equation Modeling (PLS-SEM). California: SAGE Publications.

Martinsen, U., \& Björklund, M. (2012). Matches and gaps in the green logistics market. International Journal of Physical Distribution \& Logistics Management, 42(6), 562-583. https://doi.org/10.1108/09600031211250596

Pazirandeh, A., \& Jafari, H. (2013). Making sense of green logistics. International Journal of Productivity and Performance Management, 62(8), 889-904. https://doi.org/10.1108/IJPPM-03-2013-0059

Perotti, S., Zorzini, M., Cagno, E., \& Micheli, G. J. L. (2012). Green supply chain practices and company performance: the case of 3PLs in Italy. International Journal of Physical Distribution \& Logistics Management, 42(7), 640-672. https://doi.org/10.1108/09600031211258138

Plunkett, J. W. (2009). Plunkett's Transportation, Supply Chain \& Logistics Industry Almanac 2009. Plunkett Research, Ltd. 
Rouse, M. (2010). 3PL (third-party logistics). Retrieved January 6, 2018, from https://searcherp.techtarget.com/definition/3PL-third-party-logistics

Selviaridis, K., \& Spring, M. (2007). Third party logistics: a literature review and research agenda. The International Journal of Logistics Management, 18(1), 125-150.

Zailani, S. H. M., Eltayeb, T. K., Hsu, C.-C., \& Tan, K. C. (2012). The impact of external institutional drivers and internal strategy on environmental performance. International Journal of Operations and Production Management, 32(6), 721-745. https://doi.org/10.1108/01443571211230943

Zhu, Q., Sarkis, J., \& Lai, K. H. (2012). Examining the effects of green supply chain management practices and their mediations on performance improvements. International Journal of Production Research, 50(5), 1377-1394. https://doi.org/10.1080/00207543.2011.571937

\section{Copyrights}

Copyright for this article is retained by the author, with first publication rights granted to the journal.

This is an open-access article distributed under the terms and conditions of the Creative Commons Attribution license (http://creativecommons.org/licenses/by/4.0/). 